\title{
Bidirectional Modulation of Transmitter Release by Calcium Channel/Syntaxin Interactions In Vivo
}

\author{
Ryan K. Keith, ${ }^{1}$ Robert E. Poage, ${ }^{1}$ Charles T. Yokoyama, ${ }^{2}$ William A. Catterall, ${ }^{2}$ and Stephen D. Meriney ${ }^{1}$ \\ ${ }^{1}$ Department of Neuroscience, University of Pittsburgh, Pittsburgh, Pennsylvania 15260, and ${ }^{2}$ Department of Pharmacology and Graduate Program in \\ Neurobiology and Behavior, University of Washington, Seattle, Washington 98195-7280
}

\begin{abstract}
Protein interactions within the active zone of the nerve terminal are critical for regulation of transmitter release. The SNARE protein syntaxin $1 \mathrm{~A}$, primarily known for important interactions that control vesicle fusion, also interacts with presynaptic voltage-gated calcium channels. Based on recordings of calcium channel function in vitro, it has been hypothesized that syntaxin $1 \mathrm{~A}-$ calcium channel interactions could alter calcium channel function at synapses. However, results at synapses in vitro suggest two potentially opposing roles: enhancement of neurotransmitter release by positioning docked vesicles near calcium channels and inhibition of calcium channel function by interaction with SNARE proteins. We have examined the possibility that these two effects of syntaxin can occur at synapses by studying the effects on transmitter release of manipulating syntaxin $1 \mathrm{~A}$ - calcium channel interactions at Xenopus tadpole tail neuromuscular synapses in vivo. Introduction of synprint peptides, which competitively perturb syntaxin $1 \mathrm{~A}$-calcium channel interactions, decreased quantal content at these synapses and increased paired-pulse and tetanic facilitation. In contrast, injecting mRNA for mutant (A240V, V244A) syntaxin 1A, which reduces calcium channel modulation but not binding in vitro, increased quantal content and decreased paired-pulse and tetanic facilitation. Injection of wild-type syntaxin 1A mRNA had no effect. The opposing effects of synprint peptides and mutant syntaxin 1A provide in vivo support for the hypothesis that these interactions serve both to colocalize calcium channels with the release machinery and to modulate the functional state of the calcium channel. As such, these two effects of syntaxin on calcium channels modulate transmitter release in a bidirectional manner.
\end{abstract}

Key words: calcium; syntaxin; synprint; neuromuscular junction; Xenopus; facilitation

\section{Introduction}

When an action potential depolarizes the presynaptic plasma membrane, voltage-gated calcium $\left(\mathrm{Ca}^{2+}\right)$ channels are activated and the resultant $\mathrm{Ca}^{2+}$ influx triggers synaptic vesicle fusion (Fatt and Katz, 1951; Katz and Miledi, 1967; Llinas, 1982). SNARE proteins required for exocytosis (Sollner et al., 1993; Kee et al., 1995; Sutton et al., 1998; Wu et al., 1999) interact with voltagegated $\mathrm{Ca}^{2+}$ channels (Bennett et al., 1992; Yoshida et al., 1992; Sheng et al., 1994), but the physiological significance of this interaction in vivo is unknown. Syntaxin 1A is an integral plasma membrane SNARE protein that binds SNAP25, synaptobrevin/ VAMP (vesicle-associated membrane protein), and $\mathrm{Ca}^{2+}$ channels (Trimble et al., 1988; Oyler et al., 1989; Bennett et al., 1992; Sollner et al., 1993; Hodel et al., 1994; Sheng et al., 1994; Yokoyama et al., 1997). The H3 domain of syntaxin 1A binds to the II-III intracellular loop of the $\alpha 1 \mathrm{~B}$ subunit of the N-type $\mathrm{Ca}^{2+}$ channel (the "synprint" site; amino acids 718-963) (Sheng

\footnotetext{
Received April 13, 2006; revised Nov. 21, 2006; accepted Nov. 22, 2006.

This work was supported by National Institutes of Health Grants R01 NS043396 (S.D.M.) and R01 NS22625 (W.A.C.). We thank S. Cho, K. Cosgrove, J. D. King, and F. J. Luo for many helpful discussions.

Correspondence should be addressed to Stephen D. Meriney, Department of Neuroscience, 446 Crawford Hall, University of Pittsburgh, Pittsburgh, PA 15260. E-mail: meriney@bns.pitt.edu.

R. E. Poage's present address: Department of Biology, University of North Carolina at Pembroke, Pembroke, NC 28372.

C. T. Yokoyama's present address: Neuron, Cell Press, 600 Technology Square, 5th Floor, Cambridge, MA 02139. DOI:10.1523/JNEUROSCI.4213-06.2007

Copyright $\odot 2007$ Society for Neuroscience $\quad$ 0270-6474/07/270265-05\$15.00/0
}

et al., 1994, 1998; Mochida et al., 1996; Rettig et al., 1996; Kim and Catterall, 1997). This interaction between $\mathrm{Ca}^{2+}$ channels and the release machinery has been hypothesized to be important in colocalizing these channels with proteins involved in $\mathrm{Ca}^{2+}$ sensitive vesicle fusion (Mochida et al., 1996; Rettig et al., 1997).

Synprint peptides perturb the interaction between $\mathrm{Ca}^{2+}$ channels and syntaxin 1A and reduce transmitter release (Mochida et al., 1996; Rettig et al., 1997). The decrease in transmitter release was interpreted to be attributable to dissociation of the $\mathrm{Ca}^{2+}$ channel from the $\mathrm{Ca}^{2+}$ sensor for transmitter release. Other experiments suggest that the interaction between syntaxin $1 \mathrm{~A}$ and the synprint site enhances calcium channel inactivation (Bezprozvanny et al., 1995; Wiser et al., 1996; Degtiar et al., 2000; Bergsman and Tsien, 2000; Jarvis et al., 2000, 2002; Smirnova et al., 1995; Sutton et al., 1999; Zhong et al., 1999; Zamponi, 2003). In particular, coexpression of syntaxin $1 \mathrm{~A}$ with $\mathrm{N}$-type $\mathrm{Ca}^{2+}$ channels in Xenopus oocytes increases inactivation, but a mutant form of syntaxin 1A (A240V, V244A) binds to the channel without functional effect (Bezprozvanny et al., 2000).

The potential physiological significance of this interaction of syntaxin with the presynaptic $\mathrm{Ca}^{2+}$ channel in vivo is not understood. Some have argued that this interaction aids in the colocalization of the vesicle release apparatus with presynaptic $\mathrm{Ca}^{2+}$ channels (Mochida et al., 1996; Rettig et al., 1997), whereas others have hypothesized that these interactions modulate channel function and may relay information about the vesicle docking state to $\mathrm{Ca}^{2+}$ channels (Bezprozvanny et al., 1995; Bergsman and 
Tsien, 2000). Here we have studied the functional impact of modifying presynaptic $\mathrm{Ca}^{2+}$ channel-syntaxin $1 \mathrm{~A}$ interactions in vivo using extracellular recordings of excitatory postsynaptic potentials (EPPs) at developing Xenopus tadpole tail neuromuscular synapses. Our results support the hypothesis that $\mathrm{Ca}^{2+}$ channel-syntaxin $1 \mathrm{~A}$ interactions serve both to colocalize proteins involved in $\mathrm{Ca}^{2+}$-sensitive vesicle fusion with presynaptic calcium channels and to functionally modulate $\mathrm{Ca}^{2+}$ channels at neuromuscular synapses in vivo.

\section{Materials and Methods}

Peptide/mRNA injections. Synprint peptide was prepared as described previously (Sheng et al., 1994). Purified synprint peptide (9.2 $\mathrm{nl}$ total volume; mixed 1:1 with $200 \mu \mathrm{M}$ fluorescent dextran) was injected into both blastomeres of two-cell stage Xenopus embryos treated with $2 \%$ cysteine in Normal Frog Ringer (NFR) (in mM: $116 \mathrm{NaCl}, 10$ HEPES, $2 \mathrm{KCl}, 1 \mathrm{MgCl}_{2}, 1.8$ $\mathrm{CaCl}_{2}$ ) at $\mathrm{pH} 8.5$ and bathed in $10 \%$ NFR plus $4 \%$ Ficoll. Successful injections were confirmed by immunoblots against the His tag (Rettig et al., 1997). Rat syntaxin 1A mRNA was transcribed from cDNA (kindly provided by Dr. Richard Scheller, Stanford University, Stanford, CA) using a T7 transcription kit and verified by gel electrophoresis. Mutant (A240V and V244A) syntaxin 1A cDNA was produced by Stratagene Quick Change Site-Directed Mutagenesis and verified by sequencing. Syntaxin 1A mRNA was diluted 1:750 with $\mathrm{DDH}_{2} \mathrm{O}$, mixed 1:1 with GFP mRNA, and the mixture was injected. As a control, rat GST ( $1 \mathrm{mg} / \mathrm{ml}$ in $150 \mathrm{~mm}$ potassium acetate; Sigma, St. Louis, MO) was injected into both blastomeres of two-cell stage embryos. Following $\sim 80 \mathrm{~h}$ of development (stage 42-46) (Nieuwkoop and Faber, 1967), tadpoles showing dextran or GFP fluorescence were placed in NFR, $\mathrm{pH}$ 7.4, plus $0.2 \mathrm{mg} / \mathrm{ml}$ tricaine anesthetic (Sigma). The tadpole tail was dissected, skinned, and fixed with histoacryl glue (Indermil; U.S. Surgical, Norwalk, CT) to a recording dish in NFR.

Electrophysiological recordings. Patch electrode-shaped glass pipettes were used as extracellular stimulating and recording electrodes. Recordings were made from stage 42-46 (Nieuwkoop and Faber, 1967) Xenopus tadpole tail neuromuscular synapses in NFR with $3 \mu \mathrm{M}$ curare (Bachem, King of Prussia, PA) to prevent contractions. Stimulating and recording electrodes were placed in the same chevron cleft. Paired-pulse recordings of EPPs were done at 10, 20, 40, 60, and $100 \mathrm{~ms}$ interstimulus intervals (repeated 30 times) and averaged for analysis. In the same animals, 10 stimulus pulses at $100 \mathrm{~Hz}$ were delivered to examine tetanic facilitation, and $10-15$ trials were averaged for analysis. To quantify the strength of synapses, quantal content was calculated using the failure method $(m=$ ln [trials/failures]) (del Castillo and Katz, 1954) after 150 evokedresponse trials. Acquisition and analysis were performed using pClamp software (Molecular Devices, Sunnyvale, CA). Paired-pulse ratios and tetanic facilitation were plotted as EPP amplitude of each response divided by the amplitude of the first response. Significance was determined via two-population $t$ test or ANOVA.

\section{Results}

\section{Enhanced paired-pulse facilitation by injection of} synprint peptide

To perturb $\mathrm{Ca}^{2+}$ channel interactions with SNARE proteins at synapses in vivo, we injected synprint peptides and evaluated
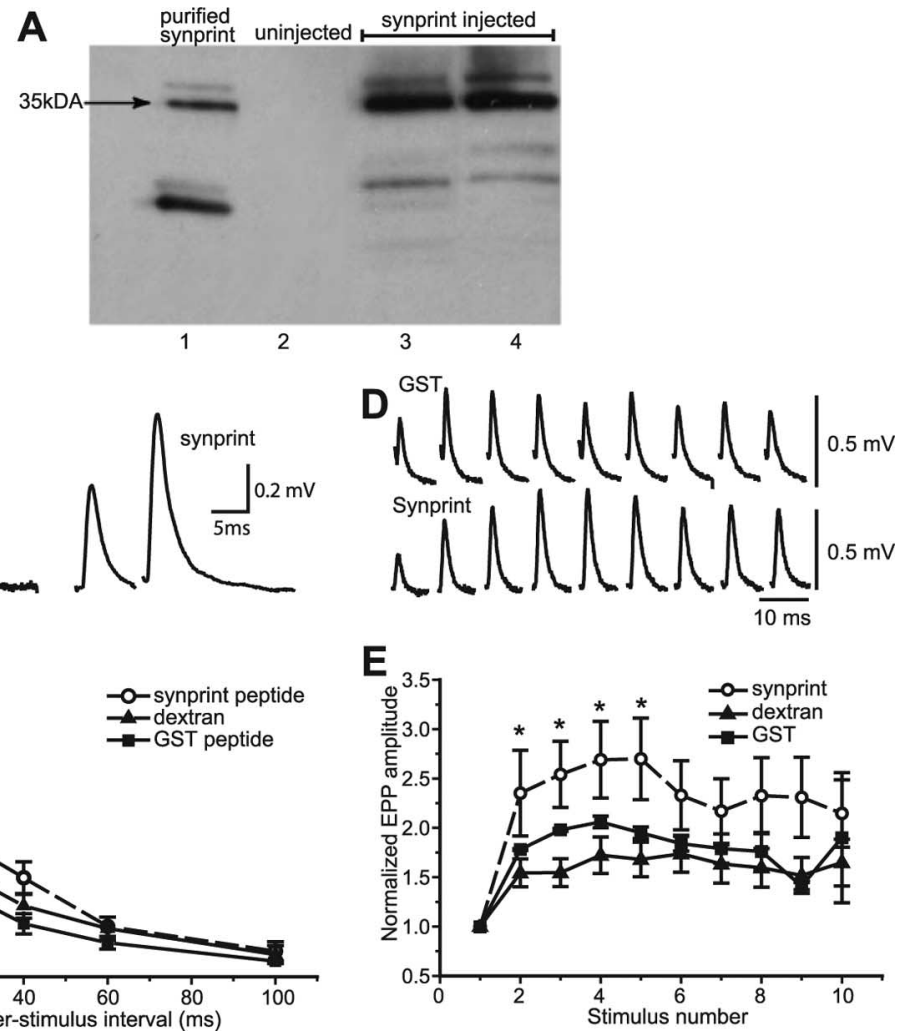

Figure 1. Effects of synprint injection on paired-pulse and tetanic facilitation. $\boldsymbol{A}$, Western blot of synprint-injected animals. Lane 1, His-tagged purified syntaxin protein. Lane 2, Homogenate from a control, uninjected Xenopus tadpole. Lanes 3 and 4 ,

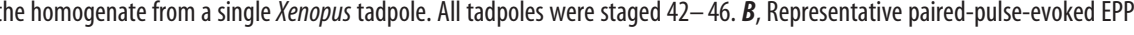
paired-pulse facilitation at the $10 \mathrm{~ms}$ interstimulus interval than control animals injected with either GST (filled $\mathrm{Hz}$ ) of EPP responses recorded from a control (GST-injected) animal (top trace) and a synprint-injected animal (bottom trace). Summary plot of tetanic facilitation (mean + SEM) recorded from synprint-injected animals (open circles, dotted line; $n=9$ ) compared with control animals injected with GST (filled squares, solid line; $n=4$ ) or fluorescent dextran (filled triangles, solid line; $n=5$ ). In $\boldsymbol{A}$ and $\boldsymbol{C}$, the stimulus artifact has been omitted for clarity. ${ }^{*}$ Significantly different, $p<0.05$, one-way ANOVA.

transmitter release at Xenopus tadpole tail neuromuscular synapses. At stage $42-46, \sim 3 \mathrm{~d}$ after injection, the animals were brightly fluorescent and synprint peptides were still present (Fig. 1A) (Rettig et al., 1997). At these ages, synapses are positioned at the ends of individual muscle cells within the clefts between chevron borders (Kullberg et al., 1977). To assay transmitter release in vivo, extracellular recordings of EPPs were made in the cleft between chevrons, and measurements of paired-pulse and tetanic facilitation were made to evaluate short-term synaptic plasticity. Synprint-injected animals (Fig. $1 B, C$ ) showed significantly greater paired-pulse facilitation than controls. When examined with 10 stimuli at $100 \mathrm{~Hz}$ (Fig. $1 \mathrm{D}, E$ ), synprint-injected animals also showed significantly greater tetanic facilitation. These data suggest that neuromuscular synapses from synprint peptideinjected animals are weaker initially and therefore are more able to exhibit facilitation.

\section{Reduced paired-pulse facilitation by overexpression of mutant syntaxin}

To contrast with synprint peptide effects, the syntaxin 1A mutant (A240V, V244A) that prevents syntaxin-mediated modulation of $\mathrm{Ca}^{2+}$ channel inactivation without affecting $\mathrm{Ca}^{2+}$ channelsyntaxin binding (Bezprozvanny et al., 2000) was used as an 
A

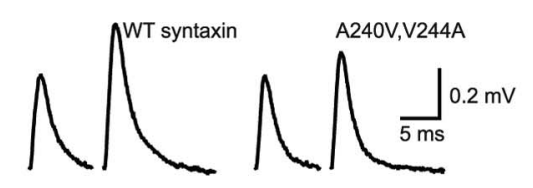

B

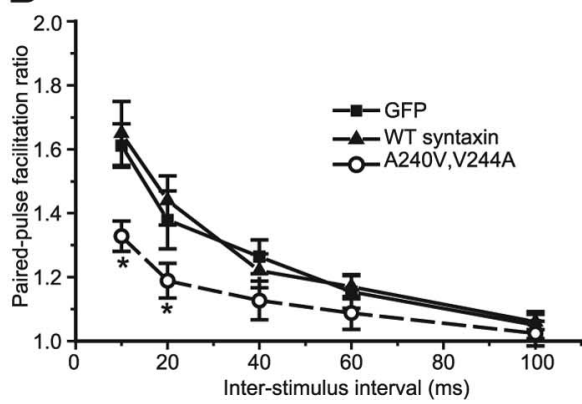

C

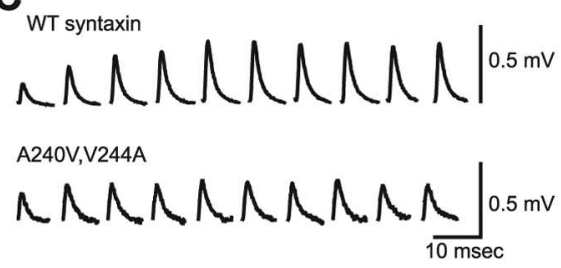

inhibitor of the syntaxin modulation of $\mathrm{Ca}^{2+}$ channel gating. Overexpression of wild-type syntaxin had no effect on pairedpulse facilitation compared with GFP alone (Fig. 2A,B). In contrast, neuromuscular synapses from mutant (A240V, V244A) syntaxin-injected animals had significantly reduced paired-pulse facilitation compared with wild-type syntaxin or GFP alone injected (Fig. $2 A, B$ ). When examined with 10 stimuli at $100 \mathrm{~Hz}$ (Fig. 2C,D), mutant (A240V, V244A) syntaxin-injected animals also showed significantly reduced tetanic facilitation. These data suggest that neuromuscular synapses from mutant (A240V, V244A) syntaxin-injected animals are initially stronger and therefore facilitate less.

\section{Comparison of effects of synprint peptides and mutant syntaxin} Comparison of mean results (Fig. 3A) shows that the four control conditions (wild-type syntaxin, GFP, GST, or fluorescent dextran) are not significantly different, whereas mutant (A240V, V244A) syntaxin reduces paired-pulse facilitation, and synprint increases paired-pulse facilitation. To test the hypothesis that synprint-injected synapses were weaker than mutant (A240V, V244A) syntaxinoverexpressed synapses, we used a failure analysis to measure quantal content. As tion $A$ Pepresentative paired-pulse-evoked EPPs recorded from a control (wild-type syntaxin m mutant (A240V, V244A) syntaxin mRNA-injected animal (right). $\boldsymbol{B}$, In the summary plot of paired-pulse responses (mean \pm SEM), mutant (A240V, V244A) syntaxin mRNA-injected animals (open circles, dotted line; $n=8$ ) had synapses with significantly reduced paired-pulse facilitation at the 10 and 20 ms interstimulus intervals compared with control animals injected with either GFP mRNA (filled squares, solid line; $n=9$ ) or wild-type syntaxin mRNA (filled triangles, solid line; $n=12$ ). $\boldsymbol{C}$, Representative tetanic facilitation (at $100 \mathrm{~Hz}$ ) of EPP responses recorded from a control (wild-type syntaxin mRNA-injected) animal (top trace) and a mutant (A240V, V244A) syntaxin mRNA-injected animal (bottom trace). D, Summary plot of tetanic facilitation (mean \pm SEM) recorded from mutant (A240V, V244A) syntaxin mRNA-injected animals (open circles, dotted line; $n=7$ ) compared with control animals injected with GFP mRNA (filled squares, solid line; $n=6$ ) or wild-type syntaxin mRNA (filled triangles, solid line; $n=4)$. In $\boldsymbol{A}$ and $\boldsymbol{C}$, the stimulus artifact has been omitted for clarity. ${ }^{*}$ Significantly different, $p<0.05$, one-way ANOVA.
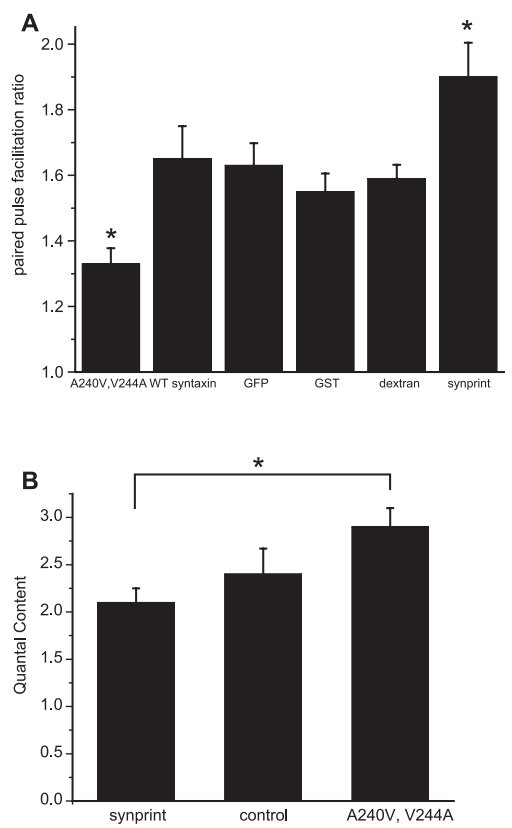

Figure 3. A, Summary plot of the effects of all experimental manipulations on paired-pulse facilitation at the $10 \mathrm{~ms}$ interstimulus interval (mean \pm SEM). Synprint-injected animals showed significantly greater paired-pulse facilitation, whereas mutant (A240V, V244A) syntaxin mRNA-injected animals showed significantly reduced paired-pulse facilitation. *Significantly different, $p<0.05$, one-way ANOVA. $\boldsymbol{B}$, Effects of experimental manipulations on quantal content as determined by failure analysis (mean \pm SEM). Synprint-injected animals had significantly smaller quantal content than mutant (A240V, V244A) syntaxin mRNA-injected animals. Quantal content estimates in control conditions $\left(1.8 \mathrm{~mm} \mathrm{Ca}^{2+}\right)$ fell between the two experimental conditions. * Significantly different, $p<0.05$, one-way ANOVA. expected, synprint-injected animals had synapses with significantly smaller quantal content than mutant (A240V, V244A) syntaxin-overexpressing animals $(2.1 \pm 0.15$ vs $2.9 \pm 0.20$; $p<$ $0.05)$, whereas the analysis of control synapses fell between these two experimental manipulations $(2.4 \pm 0.27)$ (Fig. $3 B)$.

Varying extracellular $\mathrm{Ca}^{2+}$ resulted in mild synaptic depression at $10 \mathrm{~mm}\left[\mathrm{Ca}^{2+}\right]_{\mathrm{o}}$ and progressively stronger paired-pulse and tetanic facilitation at lower $\left[\mathrm{Ca}^{2+}\right]_{\mathrm{o}}$ (Fig. $4 A, B$ ). Pairedpulse facilitation in synprint-injected animals recorded in $1.8 \mathrm{~mm}$ $\mathrm{Ca}^{2+}$ was very similar to paired-pulse facilitation recorded in controls in $1.0 \mathrm{mM} \mathrm{Ca}^{2+}$, and paired-pulse facilitation in mutant (A240V, V244A) syntaxin-injected animals recorded in $1.8 \mathrm{~mm}$ $\mathrm{Ca}^{2+}$ was comparable with that in controls using $7.5 \mathrm{mM} \mathrm{Ca}^{2+}$ (Fig. 4C). A similar overlap of synprint and mutant syntaxin data with control data at $1.0 \mathrm{mM}$ and $7.5 \mathrm{mM} \mathrm{Ca}^{2+}$, respectively, was observed in tetanic stimulation experiments (Fig. 4D). These results support the conclusion that the effects of synprint peptides and mutant syntaxin are caused by changes in calcium dynamics, reflecting alterations in calcium entry through calcium channels and calcium access to locally docked vesicles.

\section{Discussion}

\section{Biphasic regulation of synaptic transmission by $\mathrm{Ca}^{2+}$} channel/syntaxin interactions in vivo

Previous work suggests that interactions of syntaxin with calcium channels are functionally important in active zones (Catterall, 1999; Mochida, 2000; Teng et al., 2001; Atlas, 2001). Presynaptic $\mathrm{Ca}^{2+}$ channels bind syntaxin, and this interaction may serve to localize the source for $\mathrm{Ca}^{2+}$ ions near the $\mathrm{Ca}^{2+}$ sensor, increasing the efficiency of transmitter release (Mochida et al., 1996; Rettig et al., 1997). Syntaxin also increases calcium channel inactiva- 
tion, potentially reducing transmitter release, and this inhibitory effect is relieved by other SNARE proteins and synaptotagmin (Bezprozvanny et al., 1995; Smirnova et al., 1995; Wiser et al., 1996; Sutton et al., 1999; Zhong et al., 1999; Bergsman and Tsien, 2000; Degtiar et al., 2000; Jarvis et al., 2000, 2002; Zamponi, 2003). How would these apparently opposing actions affect synaptic transmission in vivo? At control synapses, some $\mathrm{Ca}^{2+}$ channels in the active zone are associated with a docked vesicle. At sites at which vesicles are docked, we hypothesize that interaction of syntaxin with synaptobrevin and synaptotagmin relieves inhibitory modulation of $\mathrm{Ca}^{2+}$ channels. At sites at which docked vesicles are not present, syntaxinmediated inhibitory modulation may inhibit $\mathrm{Ca}^{2+}$ channels, but these channels cannot efficiently initiate transmitter release; thus, disinhibition of them may have little effect on synaptic transmission.

We propose that introduction of synprint peptides perturbs syntaxin- $\mathrm{Ca}^{2+}$ channel interactions, disrupts localization of docked synaptic vesicles near calcium channels, and reverses syntaxin-mediated inhibition of calcium channels without docked vesicles. In this condition, we find that synprint peptide reduces quantal content and increases both paired-pulse and tetanic facilitation, consistent with impaired efficiency of transmitter release. Evidently, the effect of the synprint peptide to dissociate calcium channels from docked vesicles is predominant and reduces the efficiency of transmitter release, whereas the effect of synprint peptide to relieve calcium channel inhibition affects predominantly channels that are not associated with docked vesicles and therefore cannot effectively initiate transmitter release. Accordingly, the main effect of inhibition of calcium channels by syntaxin is to reduce unproductive calcium entry at sites with no nearby docked vesicles.

Following overexpression of mutant (A240V, V244A) syntaxin, SNARE protein association should be retained, whereas syntaxin-mediated inhibition of $\mathrm{Ca}^{2+}$ channels should be reduced (Bezprozvanny et al., 2000). In this case, we would predict a general increase in $\mathrm{Ca}^{2+}$ entry into the nerve terminal, which would increase transmitter release (quantal content) and reduce paired-pulse and tetanic facilitation, as we have observed. These results show that there is functionally significant modulation of presynaptic $\mathrm{Ca}^{2+}$ entry mediated by interaction of syntaxin with $\mathrm{Ca}^{2+}$ channels in vivo.

\section{Comparison with invertebrate synapses}

A homologous syntaxin mutation in Drosophila (Fergestad et al., 2001) causes more substantial loss of neurotransmission. This may reflect complete replacement of wild-type syntaxin by mutant in Drosophila versus partial replacement here or may reflect intrinsic differences between invertebrate and vertebrate synapses. Both Drosophila and Lymnaea $\mathrm{Ca}^{2+}$ channels lack a synprint site (Spafford et al., 2003b), but synprint peptides can still
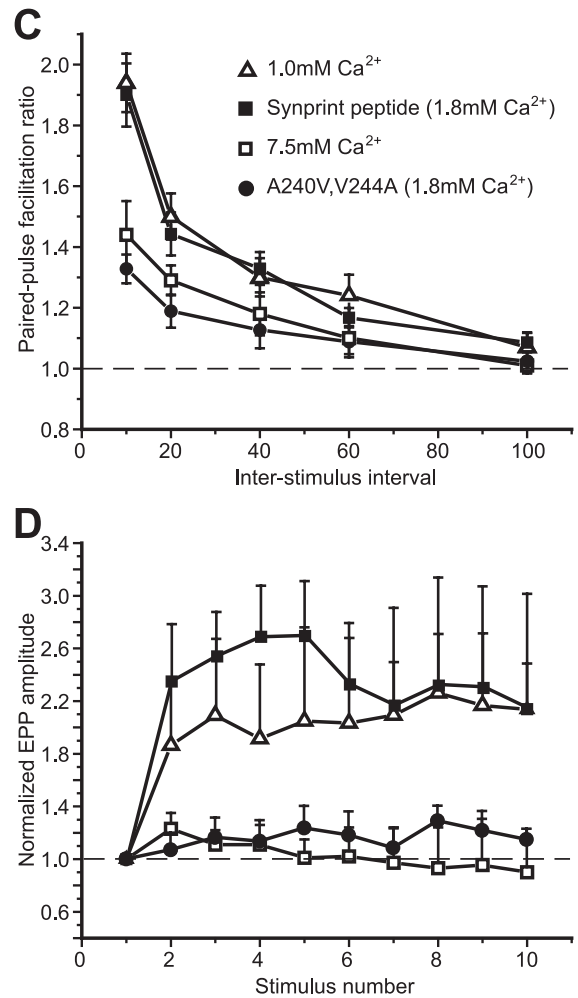

Figure 4. Effects of altering extracellular calcium concentration on paired-pulse and tetanic facilitation. All values plotted (

inhibit transmitter release in Lymnaea (Spafford et al., 2003a). Similar upstream actions of synprint peptides may contribute to their effects in vertebrate synapses, but our ability to mimic effects of synprint peptides by alterations in extracellular calcium supports the conclusion that their main effect is to dissociate docked vesicles from calcium channels.

\section{References}

Atlas D (2001) Functional and physical coupling of voltage-sensitive calcium channels with exocytotic proteins: ramifications for the secretion mechanism. J Neurochem 77: 972-985.

Bennett MK, Calakos N, Scheller R (1992) Syntaxin: a synaptic protein implicated in docking of synaptic vesicles at presynaptic active zones. Science 257:255-259.

Bergsman JB, Tsien RW (2000) Syntaxin modulation of calcium channels in cortical synaptosomes as revealed by botulinum toxin C1. J Neurosci 20:4368-4378

Bezprozvanny I, Scheller RH, Tsien RW (1995) Functional impact of syntaxin on gating of N-type and Q-type calcium channels. Nature 378:623-626.

Bezprozvanny I, Zhong R, Scheller RH, Tsien RW (2000) Molecular determinants of the functional interaction between syntaxin and $\mathrm{N}$-type $\mathrm{Ca}^{2+}$ channel gating. Proc Natl Acad Sci USA 97:13943-13948.

Catterall WA (1999) Interactions of presynaptic $\mathrm{Ca}^{2+}$ channels and SNARE proteins in neurotransmitter release. Ann NY Acad Sci 868:144-159.

del Castillo J, Katz B (1954) Quantal components of the endplate potential. J Physiol (Lond) 124:560-573.

Degtiar VE, Scheller RH, Tsien RW (2000) Syntaxin modulation of slow inactivation of N-type calcium channels. J Neurosci 20:4355-4367. 
Fatt P, Katz B (1951) An analysis of the end-plate potential recorded with an intracellular electrode. J Physiol (Lond) 115:320-370.

Fergestad T, Wu MN, Schulze KL, Lloyd TE, Bellen HJ, Broadie K (2001) Targeted mutations in the syntaxin $\mathrm{H} 3$ domain specifically disrupt SNARE complex function in synaptic transmission. J Neurosci 21:9142-9150.

Hodel A, Schafer T, Gerosa D, Burger M (1994) In chromaffin cells, the mammalian Seclp homologue is a syntaxin 1A binding protein associated with chromaffin granules. J Biol Chem 269:8623-8626.

Jarvis SE, Magga JM, Beedle AM, Braun JE, Zamponi GW (2000) G protein modulation of $\mathrm{N}$-type calcium channels is facilitated by physical interactions between syntaxin $1 \mathrm{~A}$ and G $\beta \gamma$. J Biol Chem 275:6388-6394.

Jarvis SE, Barr W, Feng ZP, Hamid J, Zamponi GW (2002) Molecular determinants of syntaxin 1 modulation of N-type calcium channels. J Biol Chem 277:44399-44407.

Katz B, Miledi R (1967) The timing of calcium action during neuromuscular transmission. J Physiol (Lond) 189:535-544.

Kee Y, Lin RC, Hsu SC, Scheller RH (1995) Distinct domains of syntaxin are required for synaptic vesicle fusion complex formation and disassociation. Neuron 14:991-998.

Kim DK, Catterall WA (1997) $\mathrm{Ca}^{2+}$-dependent and -independent interactions of the isoforms of the alpha1A subunit of brain $\mathrm{Ca}^{2+}$ channels with presynaptic SNARE proteins. Proc Natl Acad Sci USA 94:14782-14786.

Kullberg RW, Lentz TL, Cohen MW (1977) Development of the myotomal neuromuscular junction in Xenopus laevis: an electrophysiological and fine-structural study. Dev Biol 60:101-129.

Llinas R (1982) Calcium in synaptic transmission. Sci Am 247:56-65.

Mochida S (2000) Protein-protein interactions in neurotransmitter release. Neurosci Res 36:175-182.

Mochida S, Sheng ZH, Baker C, Kobayashi H, Catterall WA (1996) Inhibition of neurotransmission by peptides containing the synaptic protein interaction site of $\mathrm{N}$-type $\mathrm{Ca}^{2+}$ channels. Neuron 17:781-788.

Nieuwkoop PD, Faber J (1967) Normal table of Xenopus laevis (Daudin). Amsterdam: North-Holland.

Oyler GA, Higgins GA, Hart RA, Battenberg E, Billingsley M (1989) The identification of a novel synaptosomal-associated protein, SNAP-25, differentially expressed by neuronal subpopulations. J Cell Biol 109:3039-3052.

Rettig J, Sheng ZH, Kim DK, Hodson CD, Snutch TP, Catterall WA (1996) Isoform-specific interaction of the alphalA subunits of brain $\mathrm{Ca}^{2+}$ channels with the presynaptic proteins syntaxin and SNAP-25. Proc Natl Acad Sci USA 93:7363-7368.

Rettig J, Heinemann C, Ashery U, Sheng ZH, Yokoyama CT, Catterall WA, Neher E (1997) Alteration of $\mathrm{Ca}^{2+}$ dependence of neurotransmitter release by disruption of $\mathrm{Ca}^{2+}$ channel/syntaxin interaction. J Neurosci 17:6647-6656.
Sheng ZH, Rettig J, Takahashi M, Catterall WA (1994) Identification of a syntaxin-binding site on N-type calcium channels. Neuron 13:1303-1313.

Sheng ZH, Westenbroek RE, Catterall WA (1998) Physical link and functional coupling of presynaptic calcium channels and the synaptic vesicle docking/fusion machinery. J Bioenerg Biomembr 30:335-345.

Smirnova T, Fossier P, Stinnakre J, Mallet J, Baux G (1995) A syntaxinrelated protein controls acetylcholine release by different mechanisms in Aplysia. Neuroscience 68:125-133.

Sollner T, Bennett M, Whiteheart S, Scheller R, Rothman J (1993) A protein assembly-disassembly pathway in vitro that may correspond to sequential steps of synaptic vesicle docking, activation, and fusion. Cell 75:409-418.

Spafford JD, Munno DW, Van Nierop P, Feng Z-P, Jarvis SE, Gallin WJ, Smit AB, Zamponi GW, Syed NI (2003a) Calcium channel structural determinants of synaptic transmission between identified invertebrate neurons. J Biol Chem 278:4258-4267.

Spafford JD, Chen L, Feng Z-P, Smit AB, Zamponi GW (2003b) Expression and modulation of an invertebrate presynaptic calcium channel al subunit homolog. J Biol Chem 278:21178-21187.

Sutton RB, Fasshauer D, Jahn R, Brunger AT (1998) Crystal structure of a SNARE complex involved in synaptic exocytosis at $2.4 \mathrm{~A}$ resolution. Nature 395:347-353.

Sutton KG, McRory JE, Guthrie H, Murphy TH, Snutch TP (1999) P/Qtype calcium channels mediate the activity-dependent feedback of syntaxin-1A. Nature 401:800-804.

Teng FY, Wang Y, Tang BL (2001) The syntaxins. Genome Biol 2:3012.1-3012.7.

Trimble WS, Cowan DM, Scheller RH (1988) VAMP1: a synaptic vesicle-associated integral membrane protein. Proc Natl Acad Sci USA 85:4538-4542.

Wiser O, Bennett MK, Atlas D (1996) Functional interaction of syntaxin and SNAP-25 with voltage-sensitive $\mathrm{L}$ - and $\mathrm{N}$-type $\mathrm{Ca}^{2+}$ channels. EMBO J 15:4100-4110.

Wu M, Fergstad T, Lloyd T, He Y, Broadie K, Bellen H (1999) Syntaxin 1A interacts with multiple exocytic proteins to regulate neurotransmitter release in vivo. Neuron 23:593-605.

Yokoyama C, Sheng Z, Catterall W (1997) Phosphorylation of the synaptic protein interaction site on $\mathrm{N}$-type calcium channels inhibits interactions with SNARE proteins. J Neurosci 17:6929-6938.

Yoshida A, Oho C, Omori A, Kuwahara R, Ito T, Takahashi M (1992) HPC-1 is associated with synaptotagmin and omega-conotoxin receptor. J Biol Chem 267:24925-24928.

Zamponi GW (2003) Regulation of presynaptic calcium channels by synaptic proteins. J Pharmacol Sci 92:79-83.

Zhong H, Yokoyama CT, Scheuer T, Catterall WA (1999) Reciprocal regulation of P/Q-type $\mathrm{Ca}^{2+}$ channels by SNAP-25, syntaxin and synaptotagmin. Nat Neurosci 2:939-941. 